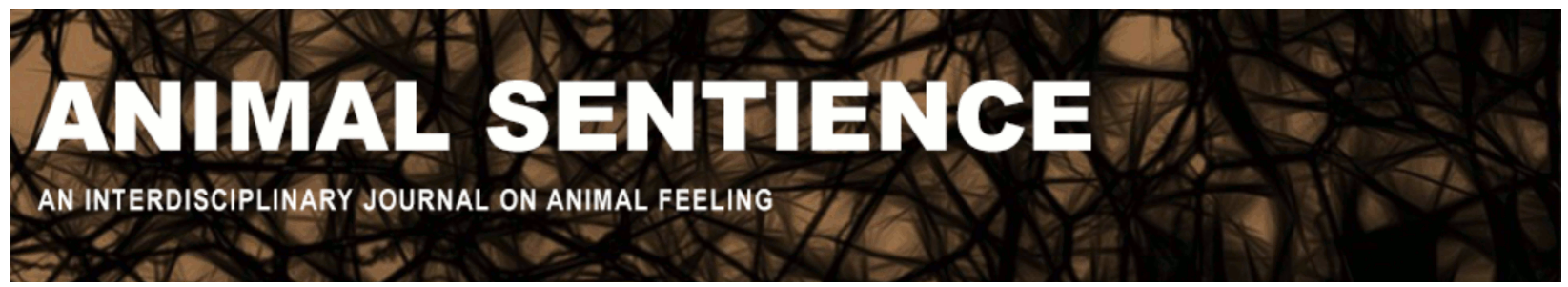

Brakel, Linda A.W. (2016) Animals are agents. Animal Sentience 10(3)

DOI: $10.51291 / 2377-7478.1125$

Date of submission: 2016-07-17

Date of acceptance: 2016-07-19

(c) (i)

This article has appeared in the journal Animal

Sentience, a peer-reviewed journal on animal

cognition and feeling. It has been made open access,

free for all, by WellBeing International and deposited

in the WBI Studies Repository. For more information,

please contact

wbisr-info@wellbeingintl.org.

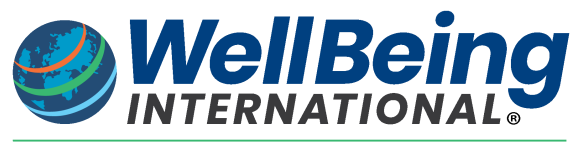

SOLUTIONS FOR PEOPLE, ANIMALS AND ENVIRONMENT 


\title{
Animals are agents
}

Commentary on Rowlands on Animal Personhood

\author{
Linda A. W. Brakel \\ Psychiatry and Philosophy \\ University of Michigan
}

\begin{abstract}
Mark Rowlands's (2016) target article invites us to consider individuals in a broad subset of the non-human animal world as genuine persons. His account features animals reacting to salient environmental stimuli as Gibsonian affordances, which is indicative of "prereflective self-awareness." He holds that such pre-reflective self-awareness is both "immune to error through misidentification" (Shoemaker, 1968) and a necessary precursor to reflective consciousness and personhood. I agree. In this commentary I hope to extend Rowlands's work with a view in which agency is an even more fundamental precursor and one can (and should) consider individuals throughout the entire animal kingdom as agents.
\end{abstract}

Linda A.W. Brakel is a psychoanalyst and an adjunct faculty member in Psychiatry and Philosophy at the University of Michigan. Her work is interdisciplinary, at the intersection of philosophy of action, philosophy of mind, and psychoanalysis. Brakel is the author of three (and coauthor/co-editor of three more) books and about 50 academic articles. https://lsa.umich.edu/philosophy/people/

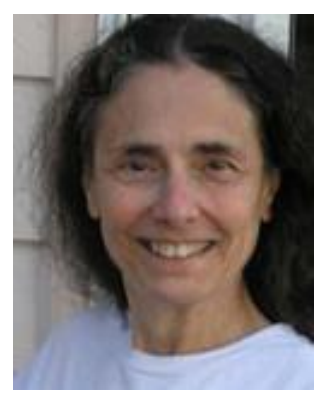
affiliated-scholars/brakel.html

\section{What Is Agency?}

G.E.M. Anscombe (1957, p. 9) famously defined agency by asking the following question: "What distinguishes actions which are intentional [agential] from those which are not?" She responded that intentional agential actions are those "to which a certain sense of the question 'Why?' is given application; ... the answer ... gives a reason for action." Anscombe considered explicability by reason(s) a necessary feature of [agential] intentional actions, adding that "the concept of ... intentional action would not exist, if the question 'Why?', with answers that give reasons for acting, did not" (p. 34).

Although these definitions of agency seem adequate for language-competent humans, the desires we share with non-human animals (along with our not-necessarily-reason(s)-based attempts to fulfill them) are also quite essential in our agency. In my own view (Brakel, 2010, chapter 4), most if not all animals are agents too. Anscombe (1957, pp. 86-87) also addressed this matter, remarking that the descriptions of many animal actions (albeit in a very few animal 
species) fit so well with descriptions of intentions that they should indeed be regarded as agential intentions. Today, however, some 60 years after Anscombe's comments, we can thanks to advances in basic concepts in evolutionary biology - develop a more comprehensive understanding of agency, which suggests a far wider membership in the club of genuine agents.

Consider animal actions that are instinctually driven, appearing irrational: cases in which it is evident that the standard reason-seeking "Why?" question has no useful application. For example, take a philosophical favorite: frogs indiscriminately swallowing both bugs and black metal BBs. This can be used to demonstrate that for animals (and for us) motives, intentions, and actions have both proximate and ultimate explanations (See Alcock, 2001, pp. 16, 130; Tinbergen, 1963). Proximate explanations are usually given in physiological and functional terms, but they can be seen answering the "Why?" question with personal volitional reasons ("the organism desires this"). Ultimate explanations answer "Why?" questions in terms of evolutionary fitness rather than volition ("this enhances reproductive success"). So why does a frog swallow all those metal BBs? Proximally, it is because the frog is hungry and has a swallowing mechanism that is triggered whenever an object - a tongue's length away or less affords an object to be swallowed. Objects to be swallowed belong to a category consisting of items of a certain size, shape, and color; bugs and BBs both belong to this category. In contrast, the ultimate reason frogs swallow BBs is that reproductive fitness is enhanced for frogs that have this swallowing mechanism even if some of the objects swallowed are not nutritive. It is irrelevant that the category of items to swallow is a disjunctive one from our human point of view (Brakel and Shevrin, 2003; Brakel, 2010, pp. 65-66). Nor is there anything necessary in this outcome. Frogs with this mechanism could have suffered nutritional disadvantage. If that had happened, or if it does in future, such frogs will have decreased reproductive success, leading eventually to fewer frogs with the BB/bug swallowing trigger in the gene pool.

Some actions can admit of both proximate and ultimate explanations simultaneously. Take the familiar chicken crossing the road. Why does she cross? Yes, she wants to get to the other side, and that is a proximate reason; but she may also be impelled to cross right now because there is food or a potential mate; or because she is being chased by a predator, etc. These are ultimate reasons in the service of enhancing her reproductive fitness.

\section{Who Is an Agent?}

These two types of explanation result in two types of answers to the "Why?" question. It follows that because ultimate evolutionary reasons should count as explanations for intentional actions no less than proximate volitional reasons, agency can and should be extended throughout the animal world. Whenever there are actions to which one or the other sense of "Why?" can apply, the actor is an agent. In this sense even amoebas should be viewed as agents as they move to engulf or extrude matter from their environs. Why does amoeba $X$ extrude that $y$-type particle now? In the ultimate sense of "Why?", extruding particles of $y$-type has increased the reproductive fitness of amoebas. Why does amoeba $X$ divide now into daughters $A$ and $B$ ? Again the ultimate explanation provides the answer. The adaptive success of $X^{\prime}$ 's genetic material is enhanced if division occurs whenever certain conditions occur. Thus according to my account, 
not only are amoebas singular agents, but they are single agents whose last agential acts under normal conditions are those involving their own division. ${ }^{1}$

I hope that the account of extended agency offered in this commentary can add to Mark Rowlands's case for extending "personhood" beyond the narrow spectrum of species currently granted membership by our membership-granting human species.

\section{References}

Alcock, S. (2001). The Triumph of Sociobiology. Oxford: Oxford University Press

Anscombe, G.E.M. (1957). Intention. Cambridge: Harvard University Press

Brakel, L.A.W. (2010). Unconscious Knowing and Other Essays in Psycho-Philosophical Analysis. Oxford: Oxford University Press

Brakel, L.A.W., \& Shevrin, H. (2003). Freud's dual process theory and the place of the arational. Behavioral and Brain Sciences, 26: 527-528.

Ramesh, M., Malik S., \& Logsdon, J. (2005). A phylogenomic inventory of meiotic genes; evidence for sex in Giardia and an early eukaryotic origin of meiosis. Current Biology, 15: 185-191.

Rowlands, M. (2016). Are animals persons? Animal Sentience 2016.101

Shoemaker, S. (1968). Self-reference and self-awareness. The Journal of Philosophy, 65: 555-567.

Tinbergen, N. (1963). On aims and methods of ethology. Zeitschrift für Tierpsychologie, 20: 410-433.

\footnotetext{
${ }^{1}$ For ameobas there are two types of reproduction. One is mitotic division, in which two genetically identical diploid daughter cells are formed. The other is meiotic division in which the paired chromosomes are first split, each part of the pair becoming a new haploid daughter cell. Then the genetic material in each is doubled again, with another division occurring after some reassembling. Not only does this constitute sexual reproduction, but the four "grandchild" haploid cells have less aged genetic material. See Ramesh, Malik, and Logsdon (2005).
} 